\title{
Analyzing the Functionality of Non-native Hsp70 Proteins in Saccharomyces cerevisiae
} Laura E. Knighton, Lizbeth P. Saa, Adam M. Reitzel and Andrew W. Truman*

Department of Biological Sciences, The University of North Carolina at Charlotte, Charlotte, USA *For correspondence: atruman1@uncc.edu

[Abstract] Yeast are an ideal system to study Heat Shock Protein 70 (Hsp70) function in a cellular context. This protocol was generated to analyze the function of non-native Hsp70 proteins by expressing them as the sole cytosolic Hsp70 in yeast. As an initial step, Hsp70 variants (such as Ssa1 point mutants and non-yeast versions such as Nematostella vectensis NvHsp70A, B and D) are cloned into an appropriate expression plasmid. Next, these plasmids are transformed into ssa1-4 4 yeast [expressing native Ssa1 from an uracil-based (URA3) plasmid] which are subsequently cured of the original yeast on 5-Fluroorotic Acid (5-FOA). The resulting cells can be screened for a variety of phenotypes which match to the activity of well-studied cellular pathways.

Keywords: Hsp70, Molecular chaperones, Nematostella, Plasmid swap

[Background] Hsp70 is a molecular chaperone that plays a role in protein folding of newly synthesized and misfolded proteins (Rosenzweig et al., 2019). It also controls the activity of regulatory proteins that contribute to cell cycle progression, protein degradation, apoptosis and resistance to anticancer therapeutics. Hsp70 is highly conserved throughout nature and is essential for cell viability. Organisms can express several highly similar Hsp70 isoforms. For example, the budding yeast Saccharomyces cerevisiae expresses 4 cytosolic isoforms, Ssa1-4 (Lotz et al., 2019). In order to characterize Hsp70 function, we can express different Hsp70 isoforms, paralogs, point mutations and truncations as the sole cytosolic Hsp70 protein in S. cerevisiae using a 5-FOA plasmid swap strategy (Boeke et al.,1987).

We were recently able to use this methodology to express Nematostella vectensis Hsp70 isoforms (NvHsp70A, B and D) in yeast and asses their functionality through phenotypic screens, growth assays and analysis of interaction partners (Waller et al., 2018; Knighton et al., 2019). These results contribute to a better understanding of Hsp70 isoform function and the potential basis of local adaptation in populations of $N$. vectensis.

\section{Materials and Reagents}

1. Pipette tips ( $10 \mu \mathrm{l}, 300 \mu \mathrm{l}, 1000 \mu \mathrm{l})$ (Neptune, catalog number: 2347 ; US Scientifica, catalog number: 1110-9700; Neptune, catalog number: 2167)

2. Eppendorf $1.5 \mathrm{ml}$ tubes (VWR, catalog number: 87003-294)

3. $15 \mathrm{ml}$ Falcon tubes (VWR, catalog number: 525-0449)

4. $50 \mathrm{ml}$ Falcon tubes (VWR, catalog number: 525-0447)

5. Petri dishes (Thermo Fisher, catalog number: FB0875713) 
6. 96-well microplate (Greiner bio-one, catalog number: 655101)

7. pAG415GPD-ccdB vector (Addgene plasmid \# 14146; http://n2t.net/addgene:14146; RRID: Addgene_14146)

8. $\quad$ Q $5^{\circledR}$ High-Fidelity $2 x$ Master Mix (NEB, catalog number: M0492S)

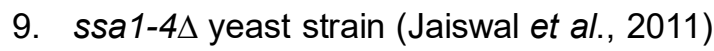

10. Top 10 E. coli cells (Invitrogen, catalog number: C404003)

11. Single-stranded carrier DNA (salmon sperm DNA, Solarbio, catalog number: D8030)

12. Tryptone (US Biological Life Sciences, catalog number: C16050360)

13. Ampicillin (Thermo Fisher, catalog number: 1159027)

14. Yeast extract (US Biological Life Sciences, catalog number: C16091364)

15. Peptone (HIMEDIA, catalog number: RM001)

16. Glucose (VWR Amresco Life Science, catalog number: 0188)

17. Agar (IBS Scientific, catalog number: IB49171)

18. Adenine hemisulfate salt (Acros Organics, catalog number: 163631000)

19. Yeast nitrogenous base (US Biological Life Sciences, catalog number: C16121501)

20. Drop out mix minus leucine, methionine, uracil (US Biological Life Sciences, catalog number: C15050101)

21. Drop out mix minus leucine (US Biological Life Sciences, catalog number: C15121094)

22. Lithium Acetate (LiAc) (Sinopharm Chemical Reagent, catalog number: 30109760)

23. Polyethylene glycol (PEG) (Sigma-Aldrich, catalog number: P3640)

24. $0.05 \mathrm{~g}$ uracil (Arcos organics, catalog number: XLE-1000)

25. 5-FOA (US biological life sciences, catalog number: 16052511)

26. Hydroxyurea (HU) (Chem-implex Int'L INC, catalog number: 24533)

27. Methyl methanesulfonate MMS (Acos organics, catalog number: 156891000)

28. Sodium chloride ( $\mathrm{NaCl})$ (VWR, amrescolife science, catalog number: 0188)

29. Cadmium chloride $\left(\mathrm{CdCl}_{2}\right)$ (Acros organics, catalog number: 42350500)

30. Hydrogen peroxide $\left(\mathrm{H}_{2} \mathrm{O}_{2}\right)$ (Sigma-Aldrich, catalog number: 216763)

31. Copper Chloride $\left(\mathrm{CuCl}_{2}\right)$ (Sigma-Aldrich, catalog number: 222011)

32. $2 \mathrm{ml}$ of methionine $(1 \mathrm{~g} / 100 \mathrm{ml}$ ) (Arcos organics, catalog number: AC166160250) (see Recipes)

33. YPDA Media ( $1 \mathrm{~L}$ ) (see Recipes)

34. Synthetic drop-out plates/media (1 L) (see Recipes)

35. 5-FOA media (1 L) (see Recipes)

36. Stock solution of $100 \mathrm{mM} \mathrm{CuCl} 2$ (see Recipes)

37. Stock solution of $\mathrm{CdCl}_{2}$ (see Recipes)

38. Chemical plates (see Recipes)

39. $1 \mathrm{M} \mathrm{LiAc}(500 \mathrm{ml})$ (see Recipes)

40. $100 \mathrm{mM}$ LiAc (500 ml) (see Recipes)

41. $50 \%$ (w/v) PEG (500 ml) (see Recipes) 


\section{Equipment}

1. UV radiator (Spectroline UV Crosslinker, model: XLE-1000)

2. $30^{\circ} \mathrm{C}$ Incubator (VWR, catalog number: 89511-422)

3. $37^{\circ} \mathrm{C}$ incubator (VWR, catalog number: 89511-428)

4. Heraeus Pico 21 Microcentrifuge (Thermo Fisher scientific, catalog number: 75002416)

5. Heraeus Multifuge X1 Centrifuge Series (Thermo Fisher scientific, catalog number: 75004211)

6. $30^{\circ} \mathrm{C}$ Incubator Shaker (New Brunswick Excella E25)

7. Thermomixer (Eppendorf, catalog number: 5382EJ909137)

8. Heat block (Thermo Scientific, catalog number: 88870000)

9. Thermal cycler (Bio-Rad, catalog number: 621BR26941)

10. Replica plater for 96-well plate 8X6 Array (Sigma-Aldrich, catalog number: R2383-1EA)

11. Autoclave (Steris Amsco Cnetury, catalog number: SG-120)

12. $\mathrm{pH}$ reader (RPI, catalog number: 850063 )

\section{Procedure}

A. Cloning of Nematostella vectensis Hsp70 isoforms into yeast expression plasmids

1. There are three Nematostella vectensis Hsp70 cytosolic isoforms; NvHsp70A, NvHsp70B, NvHsp70D.

2. We assembled the open reading frame from each $\operatorname{Hsp} 70(A, B, D)$ using sequence resources available through Nematostella JGI genome portal (https://genome.jgi.doe.gov/portal/).

3. NvHsp70A, B, and D were amplified from cDNA synthesized from RNA isolated from Nematostella vectensis originating from Massachusetts coast.

4. The published protocol for $Q 5^{\circledR}$ High-Fidelity 2x Master Mix (https://www.neb.com/protocols) was used with an annealing temperature of $60^{\circ} \mathrm{C}$ and extension time of $1 \mathrm{~min}$.

5. The following primers were used (Table 1):

Table 1. Primer sequences used for cloning NvHsp70 isoforms

\begin{tabular}{ll}
\hline Sequence Name & Sequence 5' to 3' \\
\hline Nv70D_FL_Infus_F & GTTTCGACGGATTCTAGAATGACTAAAGCACCAGCTATTGG \\
Nv70D_FL_Infus_R & GAGGTCGACGGTATCGATAAGCTTTTAGTCGACCTCCTCGATGGT \\
Nv70A_FL_Infus_F & GTTTCGACGGATTCTAGAATGGCCAAAACTCCAGCCGTTG \\
Nv70A_FL_Infus_R & GAGGTCGACGGTATCGATAAGCTTTTAGTCGACCTCCTCGATGGTA \\
Nv70B_FL_Infus_F & GTTTCGACGGATTCTAGAATGGGAAAAGCACCAGCTATTGG \\
Nv70B_FL_Infus_R & GAGGTCGACGGTATCGATAAGCTTTTAATCTACCTCTTCAATCG \\
\hline
\end{tabular}

6. Infusion cloning was used to integrate PCR products into yeast expression plasmid pAG415GPD-ccdB vector 
7. The main yeast cytosolic Hsp70, Ssa1 was used as a control.

8. All inserts were sequence confirmed with Sanger sequencing.

B. Ssa1-4 4 yeast strain

S. cerevisiae contains four isoforms of cytosolic Hsp70 (Ssa1-4), at least one of the isoforms is required in order to remain viable. The ssa1 $1 \Delta s s a 2 \Delta$ ssa3 $\Delta s s a 4 \Delta$ (ssa1-4 $\Delta$ ) pYCPlac33-SSA1 strain was generated using the loxP-kanMX-loxP gene disruption cassette. In order to keep the ssa1-4A strain, a plasmid-borne pYCPlac33-SSA1 (URA3) is needed. For more strain details, please see (Jaiswal et al., 2011).

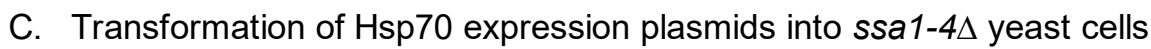

1. Inoculate 1 colony in $10 \mathrm{ml}$ of YPD (See Recipes) and incubate in a shaker overnight at $30^{\circ} \mathrm{C}$.

2. The following morning, inoculate $100 \mathrm{ml}$ of YPD with the $10 \mathrm{ml}$ overnight culture and incubate at $30{ }^{\circ} \mathrm{C}$ (shaking at $220 \mathrm{rpm}$ ) until an $\mathrm{OD} 600 \mathrm{~nm}$ of 0.5 is achieved.

3. Harvest the culture in a sterile $50 \mathrm{ml}$ centrifuge tube at $3,000 \times \mathrm{g}$ for $5 \mathrm{~min}$.

4. Pour off medium, re-suspend the cells in $25 \mathrm{ml}$ of sterile $\mathrm{H}_{2} \mathrm{O}$ and centrifuge again.

5. Pour off the $\mathrm{H}_{2} \mathrm{O}$, re-suspend the cells in $1.0 \mathrm{ml}$ of $100 \mathrm{mM} \mathrm{LiAc}$ and transfer the suspension to a sterile $1.5 \mathrm{ml}$ microfuge tube.

6. Pellet the cells at top speed for $5 \mathrm{~s}$ and remove the LiAc with a micropipette.

7. Re-suspend the cells to a final volume of $500 \mu \mathrm{l}$ which is about $400 \mu \mathrm{l}$ of $100 \mathrm{mM}$ LiAc.

8. Boil a $1.0 \mathrm{ml}$ sample of single stranded carrier DNA for $5 \mathrm{~min}$ and quickly chill in ice water.

9. Vortex the cell suspension and pipette $50 \mu \mathrm{l}$ samples into labeled microfuge tubes. Pellet the cells and remove the LiAc with a micropipette.

10. The basic "transformation mix" consists of the following ingredients; carefully add them in order listed:
a. $240 \mu \mathrm{l}$ of PEG $(50 \% \mathrm{w} / \mathrm{v})$
b. $36 \mu \mathrm{l}$ of $1.0 \mathrm{M} \mathrm{LiAc}$
c. $25 \mu \mathrm{l}$ of single stranded carrier DNA $(2.0 \mathrm{mg} / \mathrm{ml})$
d. $50 \mu \mathrm{l}$ of $\mathrm{H}_{2} \mathrm{O}$ and cloned NvHsp70 plasmid DNA (0.1-10 $\left.\mu \mathrm{g}\right)$

11. Vortex each tube vigorously until the cell pellet has been completely mixed. This usually takes about one minute.

12. Incubate the cell suspension for $30 \mathrm{~min}$ at $30^{\circ} \mathrm{C}$ shaking at $220 \mathrm{rpm}$.

13. Heat shock the cell suspension for $20-25 \mathrm{~min}$ in a water bath at $42{ }^{\circ} \mathrm{C}$.

14. Incubate on ice for $2 \mathrm{~min}$.

15. Microfuge at 5, $000 \times g$ for $15 \mathrm{~s}$ and remove the transformation mix with a micropipette.

16. Pipette $0.2-1.0 \mathrm{ml}$ of sterile $\mathrm{H}_{2} \mathrm{O}$ into each tube and re-suspend the pellet by pipetting it up and down gently.

D. Screening the positive yeast colonies on selective media 
1. Warm and dry appropriate plates in a $30^{\circ} \mathrm{C}$ incubator for at least 30 min prior to plating cells.

2. After transformation, spread the yeast cells on synthetic dropout media (SD, Recipe 2) supplemented with the appropriate nutrients to select for plasmids and incubate at $30{ }^{\circ} \mathrm{C}$ for 2 days.

3. Streak the colonies to fresh SD plates and incubate at $30^{\circ} \mathrm{C}$ for at least 1 day.

4. Streak yeast cells from previous to SD media containing 5-fluoro-orotic acid (5-FOA, Recipe 3) to counter-select for the URA3-based covering vector.

5. If the mutated or non-native Hsp70 is insufficient to keep the cells alive as the sole isoform, the cells will not grow on plates containing 5-FOA.

6. At this point, cells may be re-streaked and kept on YPD media. It is not required to keep them on SD-Leu as the Hsp70 plasmid is essential for viability.

E. Testing functionality of Hsp70 under different treatments

1. If the non-native Hsp70 is able to provide essential function as the sole Hsp70 isoform of the cell at normal conditions $\left(30^{\circ} \mathrm{C}\right)$, we can further characterize the functionality of Hsp70 by observing the cellular resistance to different stressors including heat stress $\left(37^{\circ} \mathrm{C}\right)$, DNA damage (Hydroxyurea), Oxidative stress $\left(\mathrm{H}_{2} \mathrm{O}_{2}\right), \mathrm{NaCl}$ (osmotic stress), $\mathrm{UV}$ radiation, and $\mathrm{CdCl}_{2}$ and $\mathrm{CuCl}_{2}$ (heavy metal exposure).

2. Ssa1-4 4 cells expressing NvHsp70 isoforms as their sole cytosolic Hsp70 are grown to midlogarithmic phase $(\mathrm{OD} 600 \mathrm{~nm}=0.5)$ in $10 \mathrm{ml}$ of YPDA in a $50 \mathrm{ml}$ tube.

3. Dilute cells 10 -fold serially (full concentration, 1/10 concentration, 1/100 concentration, and $1 / 1,000$ concentration) in a clear 96-well plate.

4. Cells are replica plated onto solid YPDA media containing the aforementioned chemicals or normal YPDA media and then exposed to abiotic stressors including heat stress at $37^{\circ} \mathrm{C}$ and UV radiation $\left(150 \mathrm{Jm}^{-2}, 200 \mathrm{Jm}^{-2}\right)$.

5. Concentration of drugs used are as follows; $\mathrm{HU}(200 \mathrm{mM}$ and $300 \mathrm{mM}), \mathrm{MMS}(0.04 \%, 0.08 \%)$, $\mathrm{NaCl}(0.8 \mathrm{M}, 1 \mathrm{M}), \mathrm{CdCl}_{2}(30 \mathrm{mM}, 45 \mathrm{mM}), \mathrm{CuCl}_{2}(3 \mathrm{mM}, 4 \mathrm{mM}, 5 \mathrm{mM}), \mathrm{H}_{2} \mathrm{O}_{2}(0.8 \mathrm{mM}, 1 \mathrm{mM})$.

6. After cells have dried, all plates (except for the $37^{\circ} \mathrm{C}$ plate) are kept upside-down in a $30{ }^{\circ} \mathrm{C}$ incubator for 3 days.

7. A control plate of cells replica plates on normal YPDA (kept at $30^{\circ} \mathrm{C}$ ) should be used to compare the "normal growth rate" of the non-native isoforms in yeast to that on the chemical plates, see Figure 1. 

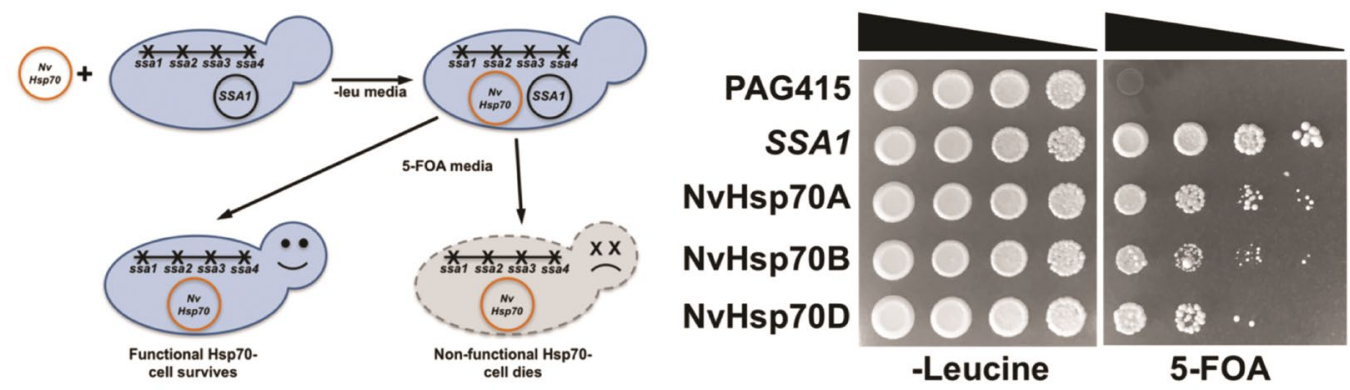

Figure 1. Expressing NvHsp70 in yeast (Waller et al., 2018). NvHsp70 isoforms provide essential Hsp70 function in yeast. Ssa1-4 $\Delta$ cells were transformed with control plasmid pAG415-ccDB, Ssa1-expressing, or NvHSP70 isoform-expressing plasmids and then serially diluted onto media lacking leucine or containing 5-FOA. Growth of cells on 5-FOA demonstrates the ability of NvHSP70 isoforms to provide essential function when expressed as the sole Hsp70 in the cell. Plates were incubated for 3 days at $30^{\circ} \mathrm{C}$ and then photographed.

\section{Data Analysis}

Photographs of the plates should be taken after a pattern of cell growth can be observed, typically after 3 days (see Figure 1).

\section{Notes}

Although this protocol describes the expression and analysis of Hsp70 isoforms from Nematostella vectensis, it can also be used to analyze Hsp70 phosphorylation site function as in (Truman et al., 2012) or allow analysis of global interactions of Hsp70 using epitope tagged versions as in (Truman et al., 2015a and 2015b; Knighton et al., 2019).

\section{Recipes}

1. $50 \%(\mathrm{w} / \mathrm{v})$ PEG $(500 \mathrm{ml})$

Dissolve $250 \mathrm{~g}$ of polyethylene glycol in $300 \mathrm{ml}$ of $\mathrm{ddH}_{2} \mathrm{O}$

Add $\mathrm{ddH}_{2} \mathrm{O}$ until final volume is $500 \mathrm{ml}$

Autoclave at $121.0^{\circ} \mathrm{C}$ on 1-hour liquid cycle

2. $1 \mathrm{M} \mathrm{LiAc}(500 \mathrm{ml})$

Dissolve $51 \mathrm{~g}$ of Lithium Acetate in $300 \mathrm{ml}$ of $\mathrm{ddH}_{2} \mathrm{O}$

Add $\mathrm{ddH}_{2} \mathrm{O}$ until final volume is $500 \mathrm{ml}$

$\mathrm{pH}$ to 7.5

Autoclave at $121.0^{\circ} \mathrm{C}$ on 1-hour liquid cycle

3. $100 \mathrm{mM} \mathrm{LiAc}(500 \mathrm{ml})$

Dilute $1 \mathrm{M}$ LiAc by $10 \mathrm{x}$ 
Autoclave at $121.0^{\circ} \mathrm{C}$ on 1-hour liquid cycle

4. YPDA Media (1 L)

$800 \mathrm{ml} \mathrm{ddH}_{2} \mathrm{O}$

$10 \mathrm{~g}$ Yeast Extract

$20 \mathrm{~g}$ Peptone

$20 \mathrm{~g}$ glucose

$40 \mathrm{mg}$ of Adenine

Add $20 \mathrm{~g}$ of Agar (for plates only)

Add $\mathrm{ddH}_{2} \mathrm{O}$ to make the volume up to $1 \mathrm{~L}$

Pour into appropriate size bottles

Autoclave at $121.0^{\circ} \mathrm{C}$ on 1-hour liquid cycle

Let cool and dry overnight at room temperature

5. Synthetic drop-out plates/media $(1 \mathrm{~L})$

$800 \mathrm{ml} \mathrm{ddH}_{2} \mathrm{O}$

\section{$6.7 \mathrm{~g} \mathrm{YNB}$}

$20 \mathrm{~g}$ glucose

$1.62 \mathrm{~g}$ Dropout mix -leu

$0.05 \mathrm{~g}$ of adenine

Adjust the $\mathrm{pH}$ to 6.0 with sodium hydroxide (if lower than 6)

Add $20 \mathrm{~g}$ of Agar (for plates only)

Add RO water to get to $1 \mathrm{~L}$

Pour into appropriate size bottles

Autoclave at $121.0^{\circ} \mathrm{C}$ on 1-hour liquid cycle

Let cool and dry overnight at room temperature

6. 5-FOA media $(1 \mathrm{~L})$

\section{$6.7 \mathrm{~g}$ YNB}

$20 \mathrm{~g}$ glucose

$1.47 \mathrm{~g}$ of -ura, -leu, -met dropout

$0.05 \mathrm{~g}$ uracil

$2 \mathrm{ml}$ of methionine

Add $20 \mathrm{~g}$ agar and make up to $1 \mathrm{~L}$

Autoclave at $121.0^{\circ} \mathrm{C}$ on 1-hour liquid cycle

After autoclaving, let it cool slightly while stirring and then add $1 \mathrm{~g}$ of FOA

Pour plates

Let cool and dry overnight at room temperature

7. Stock solution of $100 \mathrm{mM} \mathrm{CuCl} 2$

Measure $0.166 \mathrm{~g}$ of $\mathrm{CuCl}_{2}$ and mix with $15 \mathrm{ml}$ of water

8. Stock solution of $\mathrm{CdCl}_{2}$

Measure $1.67 \mathrm{~g}$ of $\mathrm{CdCl}_{2}$ and mix with $15 \mathrm{ml}$ of water 
9. Chemical plates

\section{Hydroxyurea (HU)}

a. Measure $0.76 \mathrm{~g}$ of $\mathrm{HU}$ and mix gently with $50 \mathrm{ml}$ of liquid YPDA (cool to the touch) and pour into two Petri dishes.

b. Let cool and dry overnight at room temperature

\section{MMS}

a. Measure $0.02 \mathrm{ml}$ of MMS and mix gently with $50 \mathrm{ml}$ of liquid YPDA (cool to the touch) and pour into two Petri dishes to make $0.04 \%$ MMS

b. Measure $0.04 \mathrm{ml}$ of MMS and mix gently with $50 \mathrm{ml}$ of liquid YPDA (cool to the touch) and pour into two Petri dishes to make $0.08 \%$ MMS

c. Let cool and dry overnight at room temperature

\section{$\mathrm{CuCl}_{2}$}

a. From $100 \mathrm{mM} \mathrm{CuCl}_{2}$ stock solution measure out $1.5 \mu \mathrm{l}$ and mix with $50 \mathrm{ml}$ of liquid YPDA (cool to the touch) to make a $3.0 \mathrm{mM}$ concentration and pour into two Petri dishes

b. From $100 \mathrm{mM} \mathrm{CuCl}_{2}$ stock solution measure out $2 \mu \mathrm{l}$ and mix with $50 \mathrm{ml}$ of liquid YPDA (cool to the touch) to make a $4.0 \mathrm{mM}$ concentration and pour into two Petri dishes

c. From $100 \mathrm{mM} \mathrm{CuCl}_{2}$ stock solution measure out $2.5 \mu \mathrm{l}$ and mix with $50 \mathrm{ml}$ of liquid YPDA (cool to the touch) to make a $5.0 \mathrm{mM}$ concentration and pour into two Petri dishes

d. Let cool and dry overnight at room temperature

\section{$\mathrm{CdCl}_{2}$}

a. From the $\mathrm{CdCl}_{2}$ stock solution measure out $15 \mu \mathrm{l}$ and mix with $50 \mathrm{ml}$ of liquid YPDA (cool to the touch) and pour into Petri dishes

b. From the $\mathrm{CdCl}_{2}$ stock solution measure out $22.5 \mu \mathrm{l}$ and mix with $50 \mathrm{ml}$ of liquid YPDA (cool to the touch) and pour into Petri dishes

c. Let cool and dry overnight at room temperature

\section{$\mathrm{H}_{2} \mathrm{O}_{2}$}

a. Add $40 \mu \mathrm{l}$ of $\mathrm{H}_{2} \mathrm{O}_{2}$ and mix with $50 \mathrm{ml}$ of YPDA (cool to the touch) to make $0.8 \mathrm{mM}$ concentration and pour into two Petri dishes. And let it cool overnight

b. Add $50 \mu \mathrm{l}$ of $\mathrm{H}_{2} \mathrm{O}_{2}$ and mix with $50 \mathrm{ml}$ of YPDA (cool to the touch) to make $1 \mathrm{mM}$ concentration and pour into two Petri dishes. And let it cool overnight

c. Add $75 \mu \mathrm{l}$ of $\mathrm{H}_{2} \mathrm{O}_{2}$ and mix with $50 \mathrm{ml}$ of YPDA (cool to the touch) to make $1.5 \mathrm{mM}$ concentration and pour into two Petri dishes. And let it cool overnight

d. Let cool and dry overnight at room temperature 
Please cite this article as: Knighton et. al., (2019). Analyzing the Functionality of Non-native Hsp70 Proteins in Saccharomyces cerevisiae,Bio-protocol 9

\section{$\mathrm{NaCl}$}

a. Measure $2.34 \mathrm{~g} \mathrm{NaCl}$ and mix with $50 \mathrm{ml}$ of YPDA (cool to the touch) to make a $0.8 \mathrm{M}$ concentration and pour into two Petri dishes

b. Measure $2.92 \mathrm{~g} \mathrm{NaCl}$ and mix with $50 \mathrm{~m}$ of YPDA (cool to the touch) to make a $1.0 \mathrm{M}$ concentration and pour into two Petri dishes

c. Let cool and dry overnight at room temperature

\section{Acknowledgments}

This research was supported by the National Institutes of Health NCI R15CA208773 (AWT) and National Science Foundation NSF DEB1545539 and REU \#1359271 (AMR). We thank our colleagues in both the Truman and Reitzel labs who provided assistance, insight, and comments that greatly assisted both the research and the manuscript. This protocol was adapted from our previous work (Waller et al., 2018).

\section{Competing interests}

The authors of this manuscript declare no competing interests.

\section{$\underline{\text { References }}$}

1. Boeke, J. D., Trueheart, J, Natsoulis, G. and Fink, G. R. (1987). 5-Fluoroorotic acid as a selective agent in yeast molecular genetics. Method Enzymol 154:164-175.

2. Jaiswal, H., Conz, C., Otto, H., Wolfle, T., Fitzke, E., Mayer, M. P. and Rospert, S. (2011). The chaperone network connected to human ribosome-associated complex. Mol Cell Biol 31(6): 1160-1173.

3. Knighton, L. E., Nitika, Waller, S. J., Strom, O., Wolfgeher, D., Reitzel, A. M. and Truman, A. W. (2019). Dynamic remodeling of the interactomes of Nematostella vectensis Hsp70 isoforms under heat shock. J Proteomics 206: 103416.

4. Lotz, S. K., Knighton, L. E., Nitika, Jones, G. W. and Truman, A. W. (2019). Not quite the SSAme: unique roles for the yeast cytosolic Hsp70s. Curr Genet 65(5):1127-1134.

5. Rosenzweig, R., Nillegoda, N. B., Mayer, M. P. and Bukau, B. (2019). The Hsp70 chaperone network. Nat Rev Mol Cell Biol. doi: 10.1038/s41580-019-0133-3.

6. Truman, A. W., Kristjansdottir, K., Wolfgeher, D., Hasin, N., Polier, S., Zhang, H., Perrett, S., Prodromou, C., Jones, G. W. and Kron, S. J. (2012). CDK-dependent Hsp70 Phosphorylation controls G1 cyclin abundance and cell-cycle progression. Cell 151(6): 1308-1318.

7. Truman, A. W., Kristjansdottir, K., Wolfgeher, D., Ricco, N., Mayampurath, A., Volchenboum, S. L., Clotet, J. and Kron, S. J. (2015a). Quantitative proteomics of the yeast Hsp70/Hsp90 
Please cite this article as: Knighton et. al., (2019). Analyzing the Functionality of Non-native Hsp70 Proteins in Saccharomyces cerevisiae,Bio-protocol 9

interactomes during DNA damage reveal chaperone-dependent regulation of ribonucleotide reductase. J Proteomics 112: 285-300.

8. Truman, A. W., Kristjansdottir, K., Wolfgeher, D., Ricco, N., Mayampurath, A., Volchenboum, S. L., Clotet, J. and Kron, S. J. (2015b). The quantitative changes in the yeast Hsp70 and Hsp90 interactomes upon DNA damage. Data Brief 2: 12-15.

9. Waller, S. J., Knighton, L. E., Crabtree, L. M., Perkins, A. L., Reitzel, A. M. and Truman, A. W. (2018). Characterizing functional differences in sea anemone Hsp70 isoforms using budding yeast. Cell Stress Chaperones 23(5): 933-941. 